\title{
Efektivitas Penurunan Chemichal Oxygen Demand (COD) dan pH Limbah Cair Industri Tahu dengan Tumbuhan Melati Air melalui Sistem Sub-Surface Flow Wetland
}

\author{
Anggrika Riyanti, Monik Kasman, dan Muhammad Riwan
}

Program Studi Teknik Lingkungan Universitas Batanghari

*e-mail : anggrika.riyanti@ unbari.ac.id

\begin{abstract}
ABSTRAK
Sebagian industri tahu di Kota Jambi merupakan industri rumah tangga, dimana limah cair sisa pengolahan dibuang ke lingkungan tanpa adanya pengolahan terlebih dahulu. Penelitian ini bertujuan untuk menganalisis pengaruh waktu tinggal dan efektivitas penurunan konsentrasi COD dan netralisasi $\mathrm{pH}$ pada limbah cair industri tahu dengan menggunakan sistem sub surface flow wetlands (SSF-wetland) yang dikombinasikan dengan sistem filtrasi. Tanaman yang dipilih pada penelitian ini adalah melati air (Echinodorus palaefolius). Variabel waktu tinggal air limbah di dalam reaktor adalah 5, 7, 9, 11, 13 dan 15 hari. Penurunan konsentrasi COD dan peningkatan $\mathrm{pH}$ dianalisis dengan membandingkan $\mathrm{pH}$ influen dan efluen dari sampel air limbah, serta pengaruh waktu tinggal terhadap efektivitas penurunan parameter pada masing-masing sistem . Bakumutu mengacu pada peraturan Menteri Lingkungan Hidup dan Kehutanan Nomor 68 Tahun 2016. Hasil penelitian menunjukkan kinerja yang sangat baik dari kombinasi kedua sistem dimana terjadi peningkatan $\mathrm{pH}$ awal dengan kisaran $\mathrm{pH} 3$ menjadi $\mathrm{pH}$ 6,5-7. Efisiensi penurunan konsentrasi COD mencapai 47-94\% selama waktu tinggal 15 hari dengan nilai konsentrasi mencapai $125 \mathrm{mg} / \mathrm{l}$, mendekati nilai bakumutu yaitu 100 $\mathrm{mg} / \mathrm{l}$. Waktu tinggal memberikan pengaruh yang lebih signifikan terhadap penurunan COD pada sistem SSF-Wetland daripada sistem filtrasi. Sedangkan pada parameter $\mathrm{pH}$, waktu tinggal tidak memberikan pengaruh yang signifikan pada kedua sistem.
\end{abstract}

Kata kunci : Limbah cair; Industri tahu; Melati air; Sub-surface flow wetland.

\begin{abstract}
Some of tofu industries in Jambi City are household industries, where the wastewater from processing unit was disposed of into the environment without treatment. This study aims to analyze the effect of detention time and the effectiveness of decreasing COD concentration and $\mathrm{pH}$ neutralization on wastewater of tofu industry using a sub surface flow - wetlands (SSF-wetland) system combined with a filtration system. The plant selected in this study was water jasmine (Echinodorus palaefolius). Variables of waste water detention time in the reactor are 5, 7, 9, 11, 13 and 15 days. Decreasing of COD concentration and increasing of pH were analyzed by comparing influent and effluent from wastewater samples, also the effect of detention time on the effectiveness of parameter reducing on each system. The water quality standard refers to the regulation of the Minister of Environment and Forestry Number 68 Year 2016. The results showed excellent performance from a combination of the two systems where an initial pH with range of 3 increase to $\mathrm{pH}$ 6.5-7. The efficiency of reducing COD concentration reached 47-94\% during the 15-day detention time with concentration value $125 \mathrm{mg} / \mathrm{l}$, close to the standard value $100 \mathrm{mg} / \mathrm{l}$. The residence time has more significant effect on the reduction of COD in the SSF-Wetland system than the filtration system. Whereas in pH parameters, the residence time does not have a significant effect on both systems.
\end{abstract}

Keywords: Wastewater; Tofu industries; Water jasmine; Sub-surface flow wetland

\section{Pendahuluan}

Industri tahu merupakan usaha yang didirikan dalam rangka pengembangan kegiatan di bidang pangan yang mempunyai dampak positif dan negatif bagi lingkungan. Dampak positifnya berupa pemenuhan kebutuhan masyarakat akan sumber pangan sedangkan dampak negatif berupa limbah padat (ampas tahu) dan limbah cair yang menimbulkan pencemaran lingkungan (Muhajir, 2013).

Limbah industri tahu dibagi menjadi 2 (dua) bentuk limbah, yaitu limbah padat dan limbah cair. Limbah padat pabrik pengolahan tahu berupa kotoran hasil pembersihan kedelai (batu, tanah, kulit kedelai, dan benda padat lain yang menempel pada kedelai) dan sisa saringan bubur kedelai yang disebut dengan ampas tahu.
Limbah padat yang berupa kotoran berasal dari proses awal (pencucian) bahan baku kedelai dan umumnya limbah padat yang terjadi tidak begitu banyak $(0,3 \%$ dari bahan baku kedelai). Sedangkan limbah padat yang berupa ampas tahu terjadi pada proses penyaringan bubur kedelai. Ampas tahu yang terbentuk besarannya berkisar antara 25-35\% dari produk tahu yang dihasilkan (Syah, 2011).

Limbah cair industri tahu pada umumnya memiliki karakteristik berupa pH, TSS (Total Suspended Solids), COD (Chemical Oxygen Demand), BOD (Biochemical Oxygen Demand), amoniak, minyak dan lemak, nitrit, dan nitrat yang tinggi (Kasman, et. al., 2018). COD atau Kebutuhan Oksigen Kimia (KOK) merupakan merupakan salah satu parameter yang penting dalam 
menentukan tingkat pencemaran bahan organik pada air limbah. COD merupakan banyaknya oksigen yang dibutuhkan untuk mengoksidasi bahan organik dan anorganik secara kimia di dalam air. Angka COD merupakan ukuran tingkat pencemaran air oleh zat - zat organik yang secara alamiah dapat dioksidasikan melalui proses mikrobiologis, serta mengakibatkan berkurangnya oksigen terlarut di dalam air.

Salah satu teknologi alternatif yang dapat digunakan untuk mengolah limbah cair industri tahu adalah dengan sistem lahan basah buatan (constructed wetland). Lahan Basah Buatan (Constructed wetland) merupakan sistem yang memanfaatkan media seperti lahan rawa, dengan air yang berasal dari air limbah dan ditumbuhi vegetasi air yang berfungsi sebagai pereduksi bahan pencemar yang terdapat dalam limbah (Riyanti, et. al., 2015; Poedjowibowo, 2011; Rani, et. al., 2011). Sistem ini efektif dalam menyisihkan BOD sebesar $65-90 \%$, TSS $70-95 \%$, nitrogen $15-40 \%$, fosfor $30-45 \%$, surfaktan $46 \%$ dan Fecal Coliform mencapai 99\% (Morel and Diener, 2006).

Sistem ini banyak digunakan untuk pengolahan grey water, namun pada beberapa penelitian telah menggunakan sistem constructed wetland untuk mereduksi pencemar dalam limbah tahu. Pada penelitian Kasman, et. al. (2018), penurunan BOD, TSS dan minyak lemak pada limbah industri tahu dengan waktu tinggal 15 hari dapat mencapai tingkat efisiensi sebesar 52-95\%, 45-67\% dan 59-78\%.

Sistem lahan basah buatan dalam pengolahan limbah cair dibagi menjadi 2 jenis yaitu jenis aliran permukaan (surface flow) dan aliran bawah permukaan (sub surface flow). Namun karena jenis air yang digunakan adalah air limbah, penggunaan surface flow dapat menyebabkan peningkatan jumlah nyamuk di sekitar lokasi (Supradata, 2005), sehingga sistem sub surface flow lebih cocok digunakan sebagai alternatif sistem pengolahan air limbah.

Sistem lahan basah buatan aliran bawah permukaan (Sub surface flow - Wetland) atau disingkat SSFWetland merupakan kolam yang diisi dengan media koral yang dicampur tanah sebagai media tanam, kemudian ditanami tumbuhan air sebagai penyaring pencemar dalam air limbah. Tumbuhan air (hydrophita) pada sistem ini memegang peranan penting dalam proses pemulihan kualitas air limbah secara alamiah (self purification). Sistem perakaran tumbuhan air mendukung pelepasan oksigen oleh akar tanaman air yang menyebabkan air/tanah di sekitar rambut akar memiliki oksigen terlarut yang lebih tinggi dibandingkan dengan air/tanah yang tidak ditumbuhi tanaman air. Kondisi ini sangat baik sebagai tempat hidup organisme mikro pengurai seperti bakteri aerob dapat hidup dalam lingkungan lahan basah.

Beberapa tumbuhan air yang dapat digunakan dalam SSF-Wetland antara lain Thypa sp., Scirpus sp.,
Phragmites australis, Cyperus sp., Caladium dan Echinodorus palaefolius (melati air) (Supradata, 2005; Nurdiana, 2013). Melati air merupakan tanaman hias yang akarnya terletak pada dasar perairan dan reproduksinya secara fleksibel. Tumbuhan ini dapat digunakan pada fitoremediasi karena dapat menurunkan kadar nutrien (eutrofikasi) pada perairan. Selain itu, dari segi estetika, tumbuhan ini dinilai dapat memberi kesan keindahan dan menyegarkan udara.

Pada penelitian ini, sistem SSF-Wetland dikombinasikan dengan sistem filtrasi dengan tujuan untuk pemisahan padatan tersuspensi dan mengurangi kekeruhan dalam air limbah. Penelitian ini dimaksudkan untuk mengetahui efisiensi dan pengaruh waktu tinggal terhadap netralisasi $\mathrm{pH}$ dan penurunan parameter COD dalam air limbah industri tahu melalui pengolahan dengan sistem filtrasi dan SSF-Wetland.

\section{Metode Penelitian}

Penelitian ini menggunakan tanaman melati air sebagai tanaman fitoremediasi yang berfungsi untuk mereduksi bahan pencemar dalam limbah cair industri tahu. Limbah cair industri tahu akan diolah menggunakan dua kali perlakuan yaitu reaktor dengan sistem filtrasi kemudian dialirkan ke reaktor dengan sistem SSFwetland. Variabel bebas yag digunakan yaitu waktu tinggal (td) air limbah di dalam reaktor selama 5, 7, 9, 11, 13 dan 15 hari. Sedangkan variabel terikat dalam penelitian ini adalah parameter pencemar limbah domestik meliputi $\mathrm{pH}$ dan COD.

Reaktor pertama adalah bak filtrasi dengan panjang $50 \mathrm{~cm}$, lebar $30 \mathrm{~cm}$ dan tinggi $30 \mathrm{~cm}$. Media yang digunakan pada reaktor filtrasi disusun secara berurutan dari bagian dasar bak yaitu pecahan genteng dengan ketebalan $6 \mathrm{~cm}$, karbon aktif $5 \mathrm{~cm}$, pasir silika $5 \mathrm{~cm}$, dan batu ziolit $5 \mathrm{~cm}$. Air limbah kemudian dialirkan ke rekator kedua yaitu bak $S S F$-wetland dengan dimensi panjang 1 meter, lebar $30 \mathrm{~cm}$ dan tinggi $30 \mathrm{~cm}$. Media tanam pada reaktor SSF-wetland menggunakan batu pecahan dengan ketebalan $6 \mathrm{~cm}$ dan tanah dengan ketebalan $15 \mathrm{~cm}$. Tanaman melati air ditanama pada media ini denga tujuan untuk menyerap bahan pencemar (COD) dan menetralkan $\mathrm{pH}$ dalam air limbah industri tahu tersebut. Selanjutnya pengambilan sampel air olahan diambil pada outlet bak filtrasi dan outlet bak SSF-wetland. Analisis dilakukan untuk membandingkan konsentrasi pencemar sebelum dan setelah dilakukan proses pengolahan dengan sistem filtrasi dan SSF-wetland. Baku mutu yang digunakan adalah Peraturan Menteri Lingkungan Hidup dan Kehutanan Nomor 68 tahun 2016.

\subsection{Proses Aklimatisasi}

Proses aklimatisasi tanaman melati air diperlukan untuk pengadaptasian tanaman terhadap lingkungan baru yang bertujuan untuk mengkondisikan tanaman dengan limbah yang akan diolah. Sampel air limbah industri tahu yang diambil mempunyai sacara fisik 
berwarna putih pekat dengan bau menyengat, sehingga dilakukan pengenceran sampel dengan perbandingan 1:4. Pengenceran pada saat aklimatisasi yaitu 2 liter air limbah industri tahu dicampur dengan 8 liter air bersih selanjutnya dilakukan pengadukan agar homogen. Aklimatisasi tanaman yang dilakukan yaitu mengalirkan air limbah yang telah diencerkan ke dalam reactor dan membiarkan selama 4 (empat) hari untuk memastikan tanaman tidak layu ataupun mati. Setelah itu tanaman dinetralkan kembali dengan air bersih selama 1(satu) hari lalu sebelum eksperimen dilakukan.

\subsection{Tahap Eksperimen}

Sampel air limbah cair industri tahu ditampung dalam bak penampung awal dengan jumlah 7 liter limbah tahu dan diencerkan dengan 28 liter air bersih (perbandingan pengenceran 1:4). Kemudian air limbah dialirkan dari bak penampung awal ke reaktor filtrasi selama 1 jam dengan sistem gravitasi. Sampel pertama diambil pada outlet bak filtrasi. Kemudian air limbah dialirkan ke reaktor SSF-wetland dan didiamkan dengan waktu tinggal (td) 5, 7, 9, 11, 13 dan 15 hari. Pengambilan sampel kedua diambil pada outlet bak filtrasi pada tiap waktu tinggal. Kemudian dilakukan analisis untuk membandingkan pengaruh waktu tinggal terhadap penurunan konsentrasi COD dan $\mathrm{pH}$ pada reaktor filtrasi dan reaktor $S S F$-wetland.

Pengujian sampel dilakukan di Laboratorium Dinas Lingkungan Hidup Kota Jambi dengan metode analisis parameter pH mengacu pada SNI 06-6989.11-2004, dan parameter COD mengacu pada APHA 5220 D -2005.

\section{Hasil dan Pembahasan}

\subsection{Pengaruh waktu tinggal terhadap netralisasi pH}

Efluen limbah cair industri tahu bersifat asam, dimana nilai $\mathrm{pH}$ pada sampel awal influen berkisar 1,8 hingga 3,87. Setelah dilakukan pengujian di reactor filtrasi dan $S S F$-wetland, nilai $\mathrm{pH}$ menjadi netral dengan kisaran $\mathrm{pH} 6-9$. Kondisi $\mathrm{pH}$ air limbah setelah dilakukan pengolahan pada masing-masing reaktor dapat dilihat pada Tabel 1 dan Gambar 1.

Gambar 1 menunjukkan terjadi peningkatan $\mathrm{pH}$ dari asam menuju netral setelah air limbah melewati reaktor filtrasi seiring dengan semakin lamanya waktu tinggal. Kenaikan $\mathrm{pH}$ pada sistem filtrasi ini berkisar menjadi 3,99-5,07. Hal ini menunjukkan bahwa media penyaring ikut berperan dalam mentralisasi $\mathrm{pH}$ dalam air limbah industri tahu, namun hasil yang didapat belum signifikan karena belum dapat mencapai $\mathrm{pH}$ normal. Nilai rata-rata peningkatan $\mathrm{pH}$ pada bak filtrasi adalah 4,60. dengan nilai peningkatan $\mathrm{pH}$ maksimum terjadi pada hari ke-13.

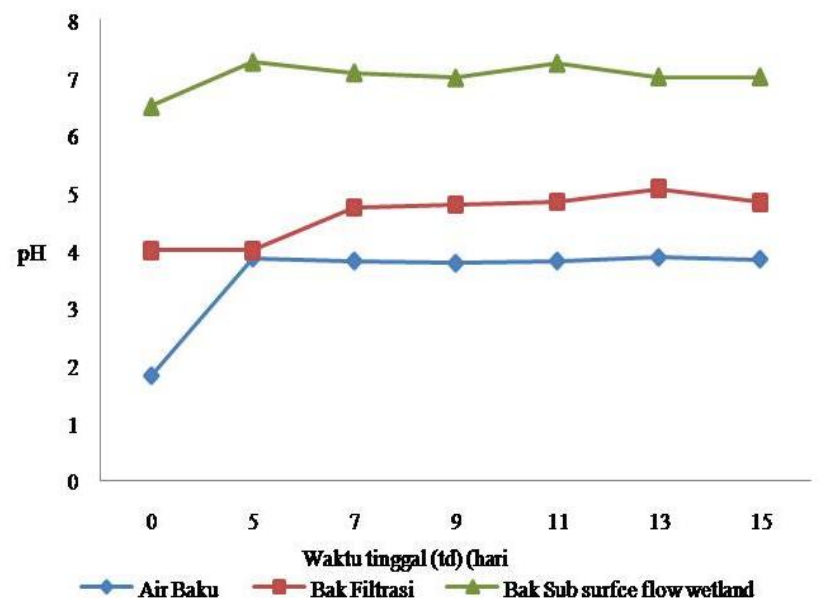

Gambar 1. Pengaruh waktu tinggal terhadap $\mathrm{pH}$

Kemudian air limbah diolah dalam reaktor SSFWetland. Hasil pengujian air effluen reaktor SSFWetland menunjukkan terjadinya peningkatan $\mathrm{pH}$ hingga 6,50-7,26 dimana $\mathrm{pH}$ air limbah menjadi netral. Nilai rata-rata peningkatan parameter $\mathrm{pH}$ pada bak sub surface flow wetland adalah 7,01 dengan nilai peningkatan $\mathrm{pH}$ tertinggi terjadi pada hari ke-7 yakni 7,26. Nilai $\mathrm{pH}$ setelah pengolahan dengan reaktor SSF-Wetland selama waktu tinggal 15 hari telah sesuai dengan batas baku mutu air limbah domestik yang tercantum pada Peraturan Menteri Lingkungan Hidup dan Kehutanan nomor 68 tahun 2016. Namun, lamanya waktu tinggal tidak memberikan pengaruh yang signifikan dalam peningkatan nilai $\mathrm{pH}$ baik pada sistem filtrasi maupun sistem SSF-Wetland (Siswanto, et.al., 2014).

\subsection{Pengaruh waktu tinggal pada penurunan COD}

Air limbah cair industri tahu mempunyai konsentrasi awal parameter COD adalah $1556 \mathrm{mg} / \mathrm{L}$. Nilai COD melebihi dari baku mutu Peraturan Menteri Lingkungan Hidup dan Kehutanan nomor 68 nomor 2016 yakni $100 \mathrm{mg} / \mathrm{L}$. Setelah dilakukan pengolahan nilai COD mengalami penurunan. Penurunan dapat dilihat pada Tabel 2 dan Gambar 2.

Tabel 1. Hasil pengujian parameter $\mathrm{pH}$

\begin{tabular}{|c|c|c|c|c|c|c|c|c|c|}
\hline \multirow[t]{2}{*}{$\mathrm{pH}$} & Baku & \multirow[t]{2}{*}{ Satuan } & \multicolumn{7}{|c|}{ Hari } \\
\hline & Mutu* & & 0 & 5 & 7 & 9 & 11 & 13 & 15 \\
\hline Reaktor filtrasi & & & 3,99 & 3,99 & 4,74 & 4,79 & 4,84 & 5,07 & 4,83 \\
\hline $\begin{array}{l}\text { Reaktor Sub Surface flow } \\
\text { Wetland }\end{array}$ & & & 6,50 & 7,26 & 7,08 & 6,99 & 7,24 & 7,01 & 7,01 \\
\hline
\end{tabular}

*) PermenLH No. 68 Tahun 2016 
Tabel 2. Hasil Pengujian Parameter COD

\begin{tabular}{|c|c|c|c|c|c|c|c|c|c|}
\hline \multirow[t]{2}{*}{ COD } & Baku & Satuan & \multicolumn{7}{|c|}{ Hari } \\
\hline & Mutu & & 0 & 5 & 7 & 9 & 11 & 13 & 15 \\
\hline Bak penampung awal & 100 & $\mathrm{mg} / \mathrm{L}$ & 1556 & 1540 & 1474 & 1580 & 1684 & 1876 & 2258 \\
\hline Reaktor filtrasi & & & 1174 & 1174 & 1288 & 1110 & 1104 & 1592 & 1971 \\
\hline Reaktor Sub Surface flow & & & 822 & 690 & 394 & 358 & 308 & 125 & 125 \\
\hline Wetland & & & & & & & & & \\
\hline
\end{tabular}

Hasil pengujian parameter COD terlihat pada bak filtrasi yang berkisaran $1050 \mathrm{mg} / \mathrm{L}$ hingga $1971 \mathrm{mg} / \mathrm{L}$. Gambar 2 menunjukkan hasil pada bak filtrasi, waktu tinggal pada hari ke-5 sampai hari ke 11 terlihat memiliki penurunan yang stabil, sedangkan hari ke 13 dan 15 penurunan kosentrasi COD cukup rendah. Hal ini dapat diakibatkan oleh kemampuan media filter yang semakin menurun karena media filter menjadi jenuh kotoran sehingga menurunkan kemampuan penyaringnya. Hal ini dapat diatasi dengan melakukan pembersihan pada media filter agar kemampuan filtrasi meningkat kembali.

Pada reaktor SSF-wetland, penurunan konsentrasi COD terjadi secara signifikan seiring dengan lamanya waktu tinggal. Penurunan konsentrasi COD sangat baik pada mulai waktu tinggal ke-5 sampai hari ke-13, dan stabil pada hari ke-15. Nilai COD mengalami penurunan mulai dari $822 \mathrm{mg} / \mathrm{l}$ hingga menjadi $125 \mathrm{mg} / \mathrm{l}$, dimana hampir mendekati nilai standar bakumutu yaitu 100 $\mathrm{mg} / \mathrm{l}$.

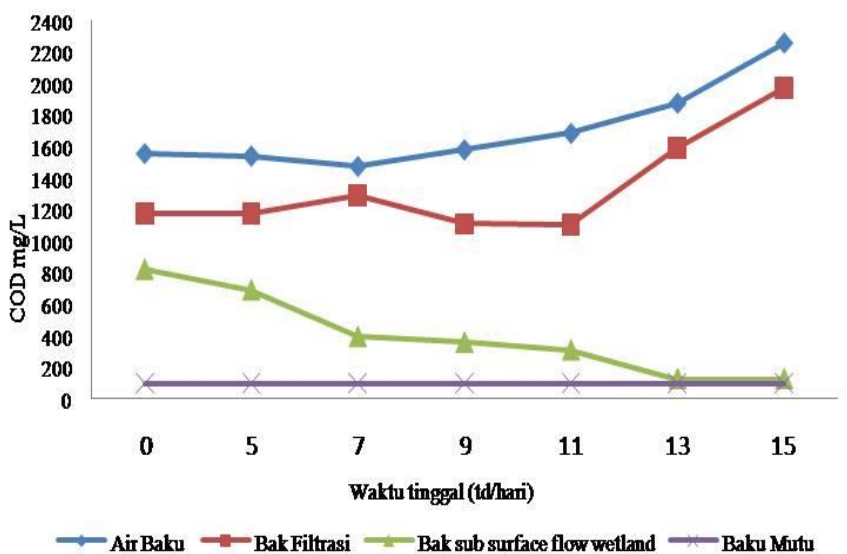

Gambar 2. Pengaruh waktu tinggal terhadap konsentrasi COD

Hasil penelitian ini sesuai dengan beberapa penelitian sebelumnya dimana penyisihan kandungan air limbah bergantung pada konsentrasi dan lamanya waktu penahanan di dalam lahan basah. Tingkat permeabilitas dan koduktivitas hidrolis media tersebut sangat berpengaruh terhadap waktu tinggal air limbah, dimana waktu tinggal yang cukup akan memberikan kesempatan kontak antara mikroorganisme dengan air limbah (Supradata, 2005; Kasman, et.al., 2018; Siswanto, et.al., 2014). Bahan organik yang terdapat didalam air limbah akan dirombak oleh mikroorganisme menjadi senyawa lebih sederhana dan akan dimanfaatkan oleh tumbuhan sebagai nutrient, sedangkan sistem perakaran tumbuhan air akan menghasilkan oksigen yang dapat digunakan sebagai sumber energi/katalis untuk rangkaian proses metabolisme bagi kehidupan mikroorganisme.

Efisiensi penurunan parameter COD dianalisis pada masing-masing reaktor yang ditampilkan pada Tabel 3. Reaktor $S S F$-wetland memiliki efisiensi yang lebih tinggi dalam menurunkan parameter COD dibandingkan filtrasi, dimana rata-rata persentase penurunan pada SSF-wetland sebesar $74 \%$ dan pada filtrasi hanya $22 \%$. Efisiensi penurunan COD pada $S S F$ wetland meningkat secara signifikan dari $47 \%$ pada hari ke-5 hingga 94\% pada hari ke-15.

Tabel 3. Efisiensi Penurunan Konsentrasi Parameter COD

\begin{tabular}{cccccc}
\hline $\begin{array}{l}\text { Hari } \\
(\mathrm{td})\end{array}$ & $\begin{array}{l}\text { Air } \\
\text { Baku }\end{array}$ & Bak Filtrasi & \multicolumn{3}{c}{$\begin{array}{l}\text { Bak sub surface flow } \\
\text { wetland }\end{array}$} \\
\cline { 2 - 6 } & & $\begin{array}{l}\text { Konsentrasi } \\
(\mathrm{mg} / \mathrm{L})\end{array}$ & $\begin{array}{l}\text { Efisiensi } \\
(\%)\end{array}$ & $\begin{array}{l}\text { Konsentrasi } \\
(\mathrm{mg} / \mathrm{L})\end{array}$ & $\begin{array}{l}\text { Efisiensi } \\
(\%)\end{array}$ \\
\hline 0 & 1556 & 1174 & 24 & 822 & 47 \\
5 & 1540 & 1174 & 23 & 690 & 55 \\
7 & 1474 & 1288 & 12 & 394 & 73 \\
9 & 1580 & 1110 & 29 & 358 & 77 \\
11 & 1684 & 1104 & 34 & 308 & 81 \\
13 & 1876 & 1592 & 15 & 125 & 93 \\
15 & 2258 & 1971 & 12 & 125 & 94 \\
\hline \multicolumn{5}{r}{ Rata - rata } \\
\hline
\end{tabular}

Tabel 3 menunjukan bahwa persentase penurunan terendah pada reaktor filtrasi terjadi di hari ke-7, kemudian meningkat dan turun kembali di hari ke-15. Sedangkan pada SSF-wetland menunjukkan persentase penurunan COD yang meningkat mulai hari ke-5 hingga hari ke-13. Jika dibandingkan dengan bak filtrasi, terlihat penurunan persentase parameter COD pada bak sub surface flow wetland lebih konsisten. Persentase penurunan pencemar meningkat seiring dengan bertambahnya waktu tinggal. Berdasarkan efisiensinya, sistem SSF-wetland dengan tanaman melati air lebih efektif dalam menurunkan parameter COD dibandingkan sistem filtrasi. Hal ini juga dipengaruhi dari bertambahnya waktu tinggal yang menyebabkan reaksi biologis yang terjadi antara limbah dan tanaman melati air semakin baik, dimana mikroorganisme yang ada pada akar tanaman akan mengikat oksigen pada air limbah cair dan mendegradasi polutan di dalam air limbah sehingga menurunkan nilai parameter COD.

\section{Kesimpulan}

Pemanfaatan sistem sub-surface flow wetland (SSFwetland) yang dikombinasikan dengan sistem filtrasi sangat baik dalam menurunkan konsentrasi parameter COD dan menetralkan $\mathrm{pH}$ pada limbah cair industri 
tahu. Kombinasi kedua sistem ini meningkatkan $\mathrm{pH}$ dalam air limbah industri tahu dari kisaran $\mathrm{pH} 3$ menjadi pH 6,5-7. Lamanya waktu tinggal tidak memberikan pengaruh yang signifikan dalam peningkatan nilai $\mathrm{pH}$ baik pada sistem filtrasi maupun pada SSF-Wetland. Sedangkan pada parameter COD, lamanya waktu tinggal memberikan pengaruh yang lebih signifikan pada sistem SSF-Wetland daripada sistem filtrasi. Konsentrasi COD menurun secara bertahap seiring dengan lamanya waktu tinggal. Efisiensi penurunan COD pada SSF-wetland mencapai $94 \%$ pada hari ke-15 dengan konsentrasi mencapai $125 \mathrm{mg} / \mathrm{l}$, mendekati bakumutu permenLH nomor 68 tahun 2016 yaitu $100 \mathrm{mg} / \mathrm{l}$.

\section{Daftar Pustaka}

Kasman, M. et.al. (2018). Reduksi pencemar limbah cair industri tahu dengan tumbuhan melati air (Echinodorus palaefolius) dalam sistem kombinasi constructed wetland dan filtrasi. Jurnal Litbang Industri, 8(1): $39-46$.

Kasman, M., Herawati, P., Aryani, N. (2018). Pemanfaatan tumbuhan melati air (Echinodorus palaefolius) dengan sistem constructed wetlands untuk pengolahan grey water. Jurnal Daur Lingkungan 1(1): 10-15.

Muhajir. 2013. Penurunan Limbah Cair BOD dan COD Pada Industri Tahu Menggunakan Tanaman Cattail (Typha Angelstifolia) dengan Construted Wetland. Jurusan Kimia Fakultas Matematika dan Ilmu Pengetahuan Alam Universitas Negeri Semarang. Semarang

Nurdiana, D.R. 2013. Inventarisasi tumbuhan air di Kebun Raya Cibodas. Depik, 2 (1): 6-9.
Poedjowibowo, D. (2011). Infrastrutur Limbah Terpadu Dalam Taman Lingkungan Permukiman. Jurnal Lanskap Indonesia, 2 (3): 90-96.

Morel, A. and Diener S. (2006). Greywater Management in Low and Middle-Income Countries, Review of different treatment systems for households or neighbourhoods. Swiss Federal Institute of Aquatic Science and Technology (Eawag). Dubendorf, Switzerland.

Rani, S.H.C, et. al. (2011). Overview of Subsurface Constructed Wetlands Application in Tropical Climates. Universal Journal of Environmental Research and Technology, 1 (2): 103-114.

Riyanti, A., Siswanto, A., Taqwa, M. R. (2015). Sistem Pengolahan Grey Water di Daerah Rawa Pasang Surut: Studi Kasus di Kabupaten Banyuasin, Sumatera Selatan. Jurnal Penelitian Universitas Jambi Seri Sains, 17 (1): 11-17.

Siswanto, et.al. (2014). Pengolahan Air Limbah Hotel Dengan Metode Free Surface Constructed Wetland Menggunakan Tumbuhan Equisetum hymale. Jurnal Ilmiah Sains Terapan, 5(1): 37-42.

Supradata. (2005). Pengolahan Limbah Domestik Menggunakan Tanaman Hias cyperus alternifolius Dalam Sistem Lahan Basah Buatan Aliran Bawah Permukaan (SSF-Wetland). Tesis Magister Ilmu Lingkungan. Universitas Diponogoro. Yogyakarta

Syah. (2011). Pengolahan Limbah Industri Tahu. Diakses pada tanggal $21 \quad$ Januari 2018 www.scribd.com/doc/56969922/pengolahan-limbahindustri-tahu-waste-management-of-tofu-industry. 